\title{
Analiza wyników testu uwagi i lateralizacji słuchowej uczniów poddanych terapii za pomocą metody Tomatisa
}

\section{The analysis of the auditory attention and hearing lateralization of pupils who received Tomatis therapy}

\author{
Marzena Mularzuk ${ }^{1,2}$, Natalia Czajka ${ }^{1,2}$, Joanna Ratyńska ${ }^{1}$, Agata Szkiełkowska ${ }^{1,2}$ \\ ${ }^{1}$ Instytut Fizjologii i Patologii Słuchu, ul. Zgrupowania AK „Kaminos” 1, 01-943 Warszawa \\ ${ }^{2}$ Światowe Centrum Słuchu, ul. Mokra 17, Kajetany, 05-830 Nadarzyn
}

Adres autora: Marzena Mularzuk, Światowe Centrum Słuchu, ul. Mokra 17, Kajetany, 05-830 Nadarzyn; e-mail:m.mularzuk@ifps.org.pl

\section{Streszczenie}

Celem pracy jest prezentacja wyników badań uczniów poddanych terapii za pomocą metody Tomatisa realizowanej w ramach projektu: „Uwaga! Sposób na sukces”. Oceny efektywności terapii dokonano na podstawie analizy wyników testów uwagi i lateralizacji słuchowej przeprowadzonych przed rozpoczęciem terapii oraz po jej zakończeniu.

Uzyskane wyniki wskazują na poprawę w zakresie wszystkich mierzonych funkcji: uwagi słuchowej zewnętrznej, uwagi słuchowej wewnętrznej, dyskryminacji dźwięków oraz lokalizacji dźwięków.

Słowa kluczowe: test uwagi i lateralizacji słuchowej • terapia Tomatisa • uwaga słuchowa

\begin{abstract}
The objective of the present paper is to present study results of the students who received Tomatis therapy, which was implemented within the project titled "Attention! A solution for success". Assessment of therapy effectiveness was conducted on the basis of analysis of auditory attention and lateralization tests performed before and after the therapy. Obtained results indicate improvement within all measured parameters: external auditory attention, internal auditory attention, sound discrimination and sound localization.
\end{abstract}

Key words: auditory attention and lateralization test $\bullet$ Tomatis therapy $\bullet$ auditory attention

\begin{abstract}
Wstęp
W ramach współpracy Instytutu Fizjologii i Patologii Słuchu, firmy Young Digital Planet oraz Europejskiego Funduszu Społecznego realizowany jest projekt „Uwaga! Sposób na sukces". Założeniem tego projektu jest poprawa jakości nauczania i uczenia się dzieci ze specjalnymi potrzebami edukacyjnymi, poprzez opracowanie i pilotażowe wdrożenie innowacyjnego programu nauczania opartego na metodzie Tomatisa wspomaganego ćwiczeniami słuchowymi oraz pracą z wykorzystaniem logorytmiki. W szczególności zaś celem projektu jest pomoc w stworzeniu warunków do efektywniejszego nauczania i uczenia się dzieci ze specjalnymi potrzebami edukacyjnymi, oraz do działań stymulujących i wspierających rozwój uwagi słuchowej.
\end{abstract}

W ramach projektu zrealizowane zostały szkolenia wśród nauczycieli, pedagogów, psychologów i logopedów umożliwiające prowadzenie terapii za pomocą metody Tomatisa na poziomie pedagogicznym. Projekt wdrożono w 62 szkołach podstawowych na terenie całego kraju. Program terapii zakładał przeprowadzenie procedury kwalifikującej uczniów na terapię Tomatisa, podczas której wykonano test uwagi i lateralizacji słuchowej. Następnie uczniowie zakwalifikowani na terapię przeszli przez trzy serie stymulacji odpowiednio przetworzonym materiałem dźwiękowym. Sesje terapeutyczne dzieliły 4-6 tygodniowe przerwy. Na zakończenie terapii ponownie został wykonywany test uwagi i lateralizacji słuchowej.

Alfred Tomatis był francuskim otolaryngologiem, który prowadził badania nad związkiem pomiędzy słuchem, głosem, mową i językiem. Efektem jego doświadczeń było wprowadzenie terapii dźwiękowej do praktyki klinicznej (głos, mowa) oraz skonstruowanie urządzenia, które pozwala na wybiórcze zwiększanie natężenia dźwięku w określonych częstotliwościach. 
Tomatis wprowadził rozróżnienie między dwoma terminami: słyszenie i słuchanie [Tomatis 1963; 1977].

Słyszenie jest procesem biernym (recepcją dźwięku) i zależy od stanu obwodowej części narządu słuchu. Prawidłowy słuch jest niezbędny dla pełnego rozwoju mowy i języka. Umożliwia odbiór bodźców akustycznych, które dostarczają informacji o otaczającym świecie, ułatwia nawiązywanie i podtrzymywanie kontaktów międzyludzkich.

Natomiast terminem słuchanie (uwaga słuchowa) określany jest proces aktywnego i świadomego odbierania bodźców dźwiękowych, wydobywania sygnałów istotnych i odrzucania nieistotnych informacji o otaczającym świecie. Jakość uwagi słuchowej zależy od funkcjonowania ośrodkowych struktur układu słuchowego oraz przepływu informacji między różnymi ośrodkami w mózgu.

Według Tomatisa słuchanie jest umiejętnością, która kształtuje się przez całe życie człowieka i może podlegać treningowi. Nawet osoby z prawidłowym wynikiem badania audiometrycznego mogą mieć problemy ze słuchaniem.

Wśród przyczyn zaburzeń uwagi słuchowej podawane są czynniki takie jak: powikłania w okresie ciąży, powikłania okołoporodowe, adopcja, wczesne oddzielenie od matki, opóźnienia rozwojowe, opóźnienie rozwoju mowy, nawracające infekcje uszu oraz uraz psychiczny lub fizyczny.

W terapii Tomatisa bardzo ważną rolę przypisuje się także lateralizacji słuchowej. Liczne badania w zakresie elektrofizjologii i neuroobrazowania wskazują na występowanie zjawiska funkcjonalnej asymetrii usznej oraz dominacji ucha specyficznej dla rodzaju prezentowanego bodźca. U większości osób praworęcznych występuje specjalizacja lewej półkuli dla bodźców werbalnych oraz prawej półkuli dla bodźców niewerbalnych oraz zjawisko przekierowania informacji z danego ucha do półkuli kontrlateralnej, a następnie dopiero do półkuli ipsilateralnej [m.in. Bylin i wsp. 1998, Binder i wsp. 2000. Foundas i wsp. 2006, Spajdel i wsp. 2007, Hughdal w wsp. 2008]. Według Tomatisa prawidłową lateralizacją dla większości osób praworęcznych jest lateralizacja prawouszna. Z uwagi na funkcjonalną specjalizację półkul mózgowych, osoby te odbierają przede wszystkim treść wypowiedzi, natomiast osoby lewouszne nieświadomie najpierw zwracają uwagę na emocjonalne zabarwienie wypowiedzi, co może utrudniać proces komunikacji. Modyfikując proces słuchania, możemy wpływać na jakość naszej percepcji dźwięków, a także na zasób przyswajanych informacji.

\section{Cel}

Celem pracy jest zaprezentowanie wyników badań uczniów poddanych terapii za pomocą metody Tomatisa, na podstawie testów uwagi i lateralizacji słuchowej wykonanych przed rozpoczęciem terapii oraz po jej zakończeniu.

\section{Material}

Do terapii zakwalifikowano 776 uczniów z 62 szkół podstawowych (masowych, z oddziałami integracyjnymi oraz specjalnych) z terenu całej Polski. Arbitralnie przyporządkowani oni zostali do poszczególnych kategorii zaburzeń przez swoich nauczycieli prowadzących lub na podstawie orzeczenia lekarskiego do jednej z kategorii jako wiodącej dla danego ucznia:

- uczniowie w normie - 433 ,

- uczniowie z mózgowym porażeniem dziecięcym - 11,

- uczniowie z zespołem Downa - 6,

- uczniowie z zespołami genetycznymi - 21,

- uczniowie z zaburzeniami mowy - 92,

- uczniowie z zaburzeniami zachowania - 46,

- uczniowie z autyzmem - 55,

- dzieci z innymi zaburzeniami - 112 .

Materiał do pracy stanowiły wyniki testów uwagi i lateralizacji słuchowej 551 uczniów, którzy posiadali kompletny test wykonany przed terapią oraz po jej zakończeniu.

\section{Metoda}

Podstawowym narzędziem badawczym w terapii Tomatisa jest opracowany przez niego test uwagi i lateralizacji słuchowej. Ściśle określone procedury pozwalają wyznaczyć krzywe uwagi słuchowej oraz sprawdzić umiejętności dyskryminacji (selekcji) wysokości dźwięków, lokalizacji dźwięków oraz lateralizację słuchową. Tomatis w opracowanym przez siebie teście wyznaczył III strefy dźwięków oraz dokładnie określił odpowiadające im częstotliwości:

- I strefa 125-750 Hz. sfera somatyczna,

- II strefa 1000-3000 Hz. sfera językowa,

- III strefa 4000-8000 Hz. sfera psychiczna.

Zaburzenia słuchania (uwagi słuchowej) mogą powodować trudności, które w znaczący sposób utrudniają funkcjonowanie dziecka $\mathrm{w}$ różnych sferach życia, jak również wiele czynników może mieć wpływ na rozwijanie się wymienionych trudności.

\section{Techniki i narzędzia badawcze}

Test uwagi i lateralizacji słuchowej, wykonywany za pomocą narzędzia badawczego-audiolaterometru, składa się z następujących elementów:

- badanie uwagi słuchowej zewnętrznej (drogą powietrzną),

- badanie uwagi słuchowej wewnętrznej (drogą kostną),

- badanie umiejętności lokalizacji dźwięku (drogą powietrzną i kostną),

- badanie umiejętności dyskryminacji wysokości dźwięku (tzw. selekcji dźwięku),

- badanie lateralizacji słuchowej.

\section{Badanie uwagi słuchowej zewnętrznej}

Uwaga słuchowa zewnętrzna jest zdolnością słuchania i przetwarzania dźwięków przychodzących „z zewnątrz”. Badanie zaczyna się od ucha prawego, później lewego i polega na wyznaczaniu uwagi słuchowej zewnętrznej według ściśle określonych reguł. W badaniu wykorzystywane są tony czyste podawane drogą powietrzną. Uwaga słuchowa zewnętrzna wykreślona zostaje dla następujących częstotliwości: $8000 \mathrm{~Hz}, 6000 \mathrm{~Hz}, 4000 \mathrm{~Hz}, 3000 \mathrm{~Hz}, 2000$ $\mathrm{Hz}, 1500 \mathrm{~Hz}, 1000 \mathrm{~Hz}, 750 \mathrm{~Hz}, 500 \mathrm{~Hz}, 250 \mathrm{~Hz}, 125 \mathrm{~Hz}$.

\section{Badanie uwagi słuchowej wewnętrznej}

Uwaga słuchowa wewnętrzna jest umiejętnością słuchania dźwięków „wewnętrznych”, czyli własnego głosu i mowy. 


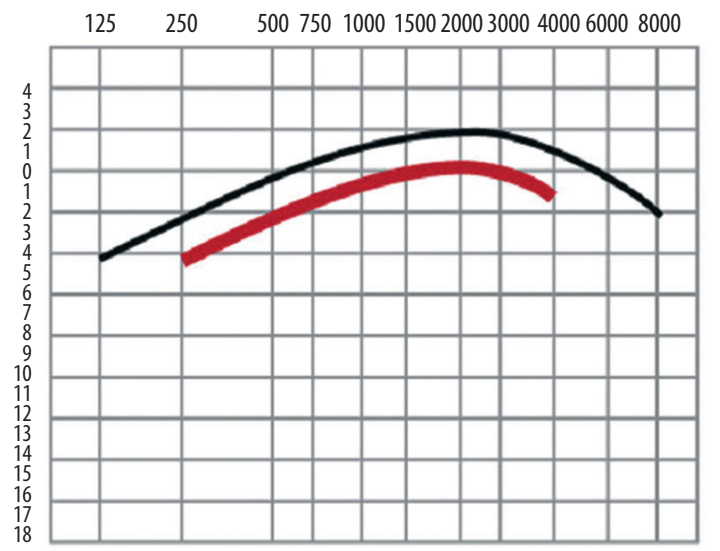

Rycina 1. Test idealny uwagi słuchowej wg Tomatisa

Własny głos i mowę słyszymy głównie na drodze kostnej (dlatego np. inaczej odbieramy własny głos, gdy mówimy, a inaczej gdy słyszymy swój głos odtworzony z nośnika dźwięku).

Procedura badania także zaczyna się od ucha prawego, następnie zaś badane jest ucho lewe. Według ściśle określonych reguł wyznaczona zostaje uwaga słuchowa wewnętrzna dla następujących częstotliwości: $4000 \mathrm{~Hz}, 3000$ $\mathrm{Hz}, 2000 \mathrm{~Hz}, 1500 \mathrm{~Hz}, 1000 \mathrm{~Hz}, 750 \mathrm{~Hz}, 500 \mathrm{~Hz}, 250 \mathrm{~Hz}$.

\section{Lokalizacja źródła dźwięku}

Badanie lokalizacji dźwięków wykonywane jest jednocześnie z badaniem uwagi słuchowej zewnętrznej i wewnętrznej i odpowiednio dla częstotliwości przypisanym uwadze słuchowej zewnętrznej oraz wewnętrznej zaznaczone zostają błędne określenia lokalizacji dźwięków.

\section{Badanie dyskryminacji wysokości dźwięków}

Badanie rozpoczyna się od ucha prawego, kolejno zaś wykonywane jest dla ucha lewego. Dźwięki wg ściśle określonej procedury prezentowane są osobie badanej za pośrednictwem przewodnictwa powietrznego dla następujących częstotliwości: $8000 \mathrm{~Hz}, 6000 \mathrm{~Hz}, 4000 \mathrm{~Hz}, 3000 \mathrm{~Hz}, 2000$ $\mathrm{Hz}, 1500 \mathrm{~Hz}, 1000 \mathrm{~Hz}, 750 \mathrm{~Hz}, 500 \mathrm{~Hz}, 250 \mathrm{~Hz}, 125 \mathrm{~Hz}$. Na arkuszu badania zaznaczane są błędne odpowiedzi w zakresie dyskryminacji wysokości dźwięków.

\section{Badanie lateralizacji słuchowej}

Badanie ocenia lateralizację słuchową w zakresie kontroli słuchowej, czyli odpowiada na pytanie, którym uchem pacjent kontroluje własne wypowiedzi.

Badanie lateralizacji słuchowej dokonywane jest poprzez zmianę natężenia między uchem prawym i lewym. W czasie gdy osoba badana słyszy swój głos w słuchawkach, badacz obserwuje reakcję motoryczną mięśni mimicznych. Według twórcy metody - Alfreda Tomatisa zwiększenie natężenia dźwięku w jednej ze słuchawek powoduje większą aktywność mięśnia strzemiączkowego po tej stronie i - ze względu na wspólne unerwienie mięśnia strzemiączkowego i mięśni twarzy - aktywację nerwu twarzowego tej strony

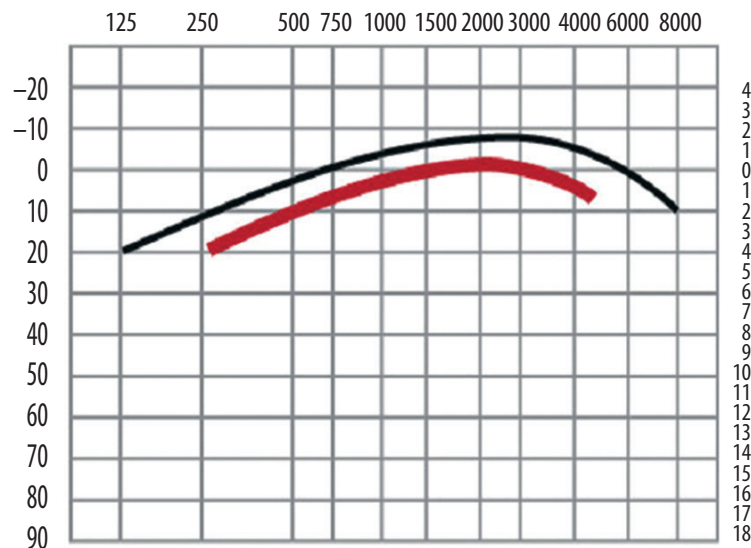

oraz nasilenie motoryki mięśni twarzy. Obserwując czynność mimiczną, wnioskujemy pośrednio o aktywności mięśnia strzemiączkowego po tej stronie. Ucho, w którym czynność ta jest większa, jest uchem „aktywnym”, wiodącym.

Z uwagi na trudności w zakresie oceny funkcji lateralizacji większość wykonanych testów nie zawierała tego parametru i wartościowa analiza w zakresie ewaluacji tego parametru nie była możliwa.

\section{Wyniki}

Wyniki uporządkowano według następujących kryteriów:

- oddzielnie percepcja prawo oraz lewouszna dla wszystkich parametrów testu,

- prezentacja wyników uwagi słuchowej zewnętrznej oraz uwagi słuchowej wewnętrznej w podziale na trzy strefy dźwięków: I 125-750 Hz, II 1000-3000 Hz oraz III 4000-8000 Hz.

Wyniki zanalizowane zostały w odniesieniu do uśrednionych parametrów prawidłowego testu uwagi i lateralizacji słuchowej.

Na Rycinie 2 przedstawiono wyniki badań dla I strefy dźwięków testu uwagi i lateralizacji słuchowej w zakresie uwagi słuchowej zewnętrznej dla percepcji prawo oraz lewousznej.

Analiza danych liczbowych testu uwagi i lateralizacji słuchowej dla strefy I uwagi słuchowej zewnętrznej dla percepcji prawo oraz lewousznej wskazała, że u 70\% badanych nastąpiła poprawa tych wyników.

Rycina 3 przedstawia wyniki badań dla II strefy dźwięków testu uwagi i lateralizacji słuchowej w zakresie uwagi słuchowej zewnętrznej dla percepcji prawo oraz lewousznej.

Wyniki badań uczniów z zakresu II strefy częstotliwości testu uwagi i lateralizacji słuchowej dla uwagi słuchowej zewnętrznej wskazują, że po zastosowaniu terapii $63 \%$ uczniów poprawiło swoje wyniki.

Na Rycinie 4 przedstawiono wyniki badań dla III strefy dźwięków testu uwagi i lateralizacji słuchowej w zakresie 


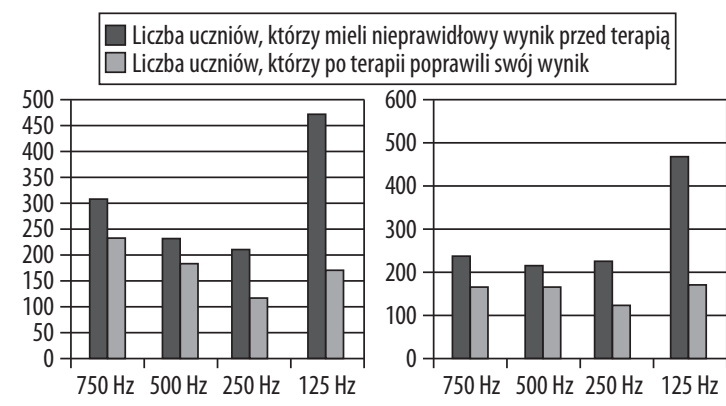

Rycina 2. Wyniki badań pacjentów dla I strefy dźwięków uwagi słuchowej zewnętrznej testu uwagi i lateralizacji słuchowej

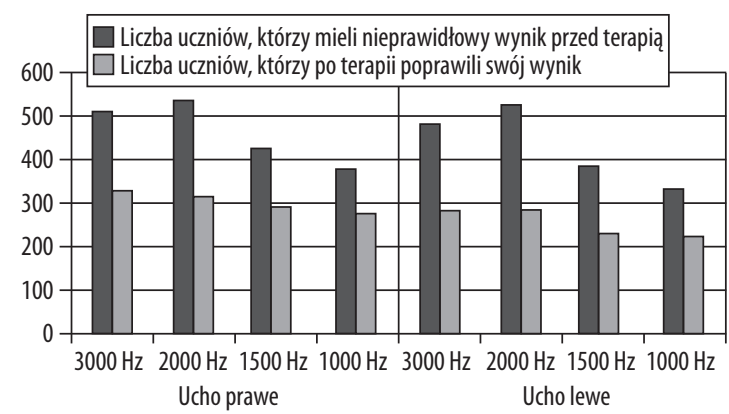

Rycina 3. Wyniki badań pacjentów dla II strefy dźwięków uwagi słuchowej zewnętrznej testu uwagi i lateralizacji słuchowej

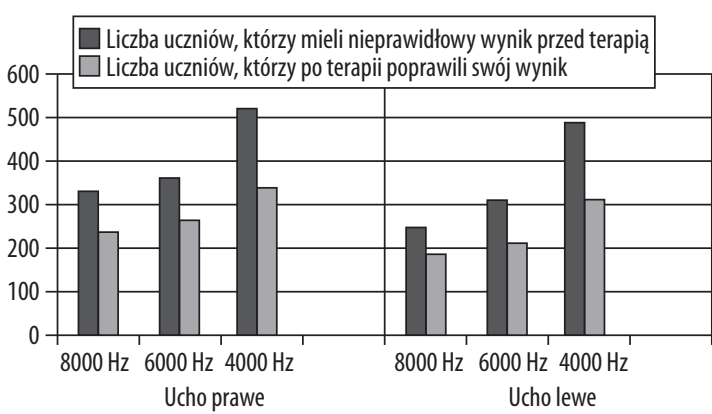

Rycina 4. Wyniki badań pacjentów dla III strefy dźwięków uwagi słuchowej zewnętrznej testu uwagi i lateralizacji słuchowej

uwagi słuchowej zewnętrznej dla percepcji prawo oraz lewousznej.

Po przeliczeniu danych wszystkich uczniów, którzy przed terapią mieli nieprawidłowy wynik w zakresie badanych częstotliwości, wynika, że po terapii $63 \%$ z tych uczniów poprawiło wyniki w zakresie percepcji słuchowej prawo i lewousznej.

Rycina 5 przedstawia wyniki badań dla I strefy dźwięków testu uwagi i lateralizacji słuchowej w zakresie uwagi słuchowej wewnętrznej dla percepcji prawo oraz lewousznej.

Analiza danych liczbowych testu uwagi i lateralizacji słuchowej dla strefy I uwagi słuchowej wewnętrznej dla percepcji prawo oraz lewousznej wskazała, że u $40 \%$ badanych nastąpiła poprawa tych wyników.

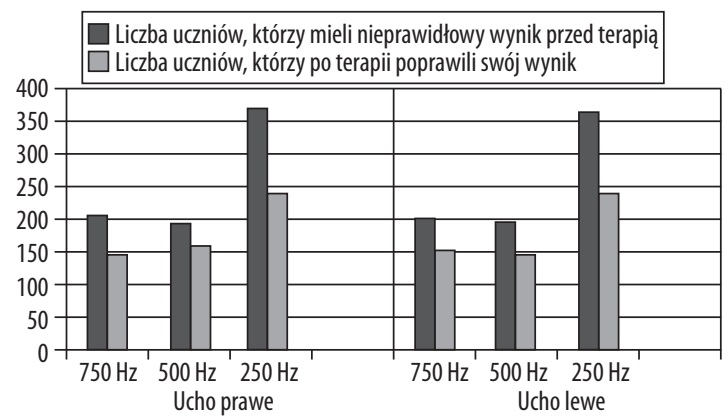

Rycina 5. Wyniki badań pacjentów dla I strefy dźwięków uwagi słuchowej wewnętrznej testu uwagi i lateralizacji stuchowej

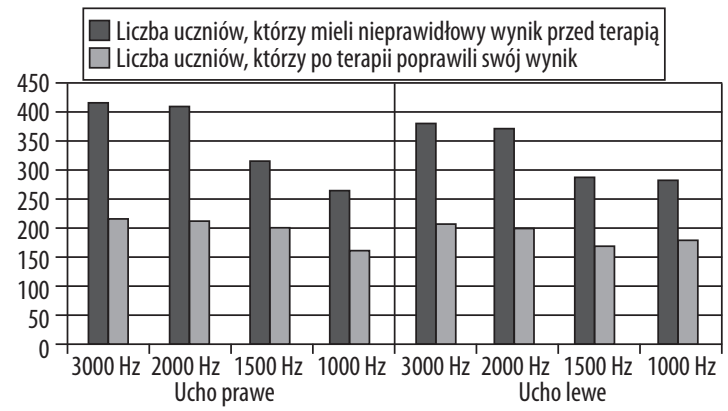

Rycina 6. Wyniki badań pacjentów dla II strefy dźwięków uwagi słuchowej wewnętrznej testu uwagi i lateralizacji słuchowej

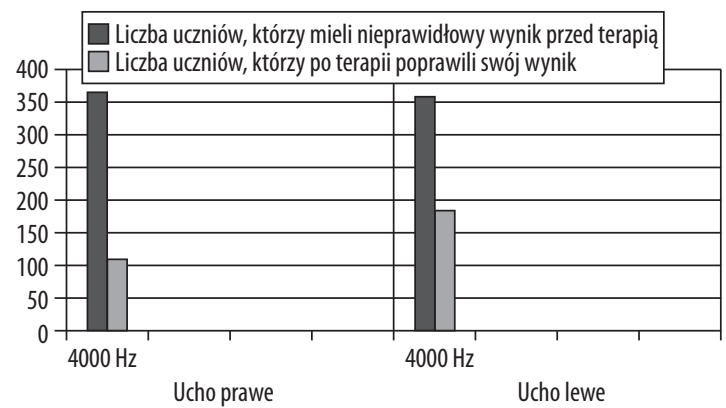

Rycina 7. Wyniki badań pacjentów dla III strefy dźwięków uwagi słuchowej wewnętrznej testu uwagi i lateralizacji słuchowej

Na Rycinie 6 przedstawiono wyniki badań dla II strefy dźwięków testu uwagi i lateralizacji słuchowej w zakresie uwagi słuchowej wewnętrznej dla percepcji prawo oraz lewousznej.

Przeliczone wyniki badań uczniów z zakresu II strefy częstotliwości testu uwagi i lateralizacji słuchowej dla uwagi słuchowej wewnętrznej wskazują, że po zastosowaniu terapii 57\% uczniów poprawiło swoje wyniki.

Rycina 7 prezentuje wyniki badań dla III strefy dźwięków testu uwagi i lateralizacji słuchowej w zakresie uwagi słuchowej wewnętrznej dla percepcji prawo oraz lewousznej.

Po przeliczeniu danych wszystkich uczniów, którzy przed terapią mieli nieprawidłowy wynik w zakresie badanej częstotliwości, wynika, że po zastosowaniu terapii $73 \%$ z tych 

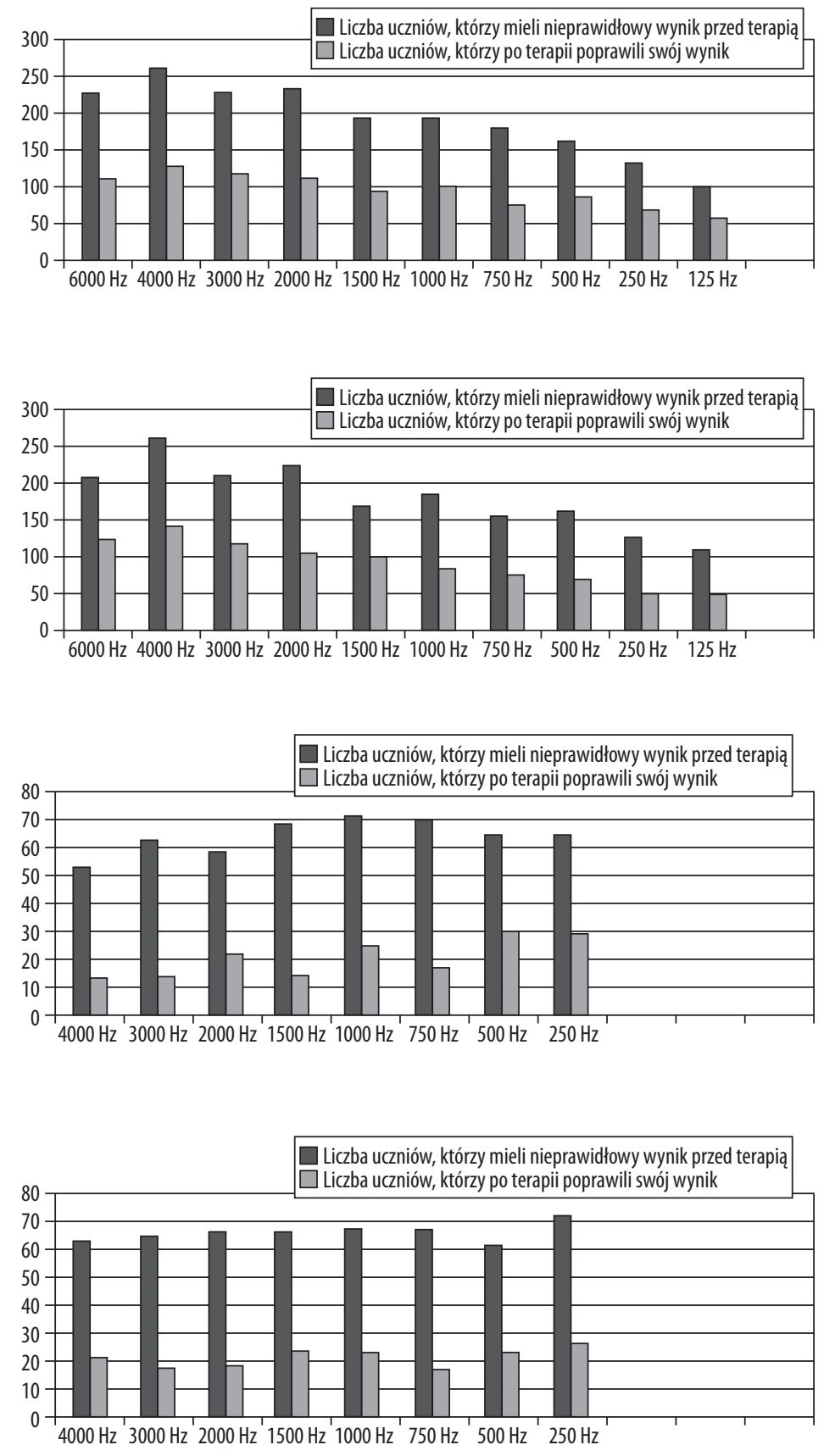

Rycina 8. Wyniki badań pacjentów w zakresie dyskryminacji dźwięków dla percepcji prawousznej

Rycina 9. Wyniki badań pacjentów w zakresie dyskryminacji dźwięków dla percepcji lewousznej

Rycina 10. Wynikibadańpacjentówwzakresie lokalizacji dźwięków za pośrednictwem przewodnictwa kostnego dla percepcji prawousznej

Rycina 11. Wynikibadańpacjentówwzakresie lokalizacji dźwięków za pośrednictwem przewodnictwa kostnego dla percepcji lewousznej uczniów poprawiło wyniki w zakresie percepcji słuchowej prawo i lewousznej.

Na Rycinie 8 przedstawiono wyniki badań testu uwagi i lateralizacji w zakresie dyskryminacji dźwięków dla percepcji prawousznej.

Po przeliczeniu danych wszystkich uczniów, którzy przed terapią mieli nieprawidłowy wynik w zakresie dyskryminacji dźwięków dla percepcji prawousznej, wynika, że po zastosowaniu terapii $50 \%$ z tych uczniów poprawiło swoje wyniki.

Rycina 9 prezentuje wyniki badań testu uwagi i lateralizacji w zakresie dyskryminacji dźwięków dla percepcji lewousznej.
Analiza danych liczbowych wszystkich uczniów, którzy przed terapią mieli nieprawidłowy wynik w zakresie dyskryminacji dźwięków dla percepcji lewousznej, wykazała, że po zastosowaniu terapii $50 \%$ z tych uczniów poprawiło swoje wyniki.

Na Rycinie 10 przedstawiono wyniki badań testu uwagi i lateralizacji w zakresie lokalizacji dźwięków za pośrednictwem przewodnictwa kostnego dla percepcji prawousznej.

Przeliczone wyniki badań z zakresu lokalizacji dźwięków za pośrednictwem przewodnictwa kostnego dla percepcji prawousznej wskazują, że po terapii $69 \%$ uczniów poprawiło swoje wyniki. 
Na Rycinie 11 przedstawiono wyniki badań testu uwagi i lateralizacji w zakresie lokalizacji dźwięków za pośrednictwem przewodnictwa kostnego dla percepcji lewousznej.

Analiza danych liczbowych wszystkich uczniów, którzy przed terapią mieli nieprawidłowy wynik w zakresie lokalizacji dźwięków za pośrednictwem przewodnictwa kostnego dla percepcji lewousznej, wykazała, że po zastosowaniu terapii $68 \%$ z tych uczniów poprawiło swoje wyniki.

We wszystkich mierzonych parametrach testu uwagi i lateralizacji słuchowej uzyskano poprawę wyników w stosunku do badania początkowego. Analiza wyników osiągniętych przez uczniów biorących udział w terapii wskazuje na dużą skuteczność zastosowanej metody stymulacji dźwiękowej i może świadczyć o przydatności treningu słuchowego we wspomaganiu uczniów w procesie uczenia się.

\section{Podsumowanie}

Dzięki treningowi uwagi słuchowej w formie terapii opracowanej przez Tomatisa możemy w sposób efektywny i zorganizowany, poprzez dźwięki o określonej częstotliwości, usprawnić zdolność słuchania. Za pomocą odpowiednio filtrowanych dźwięków stymulowane są ośrodki w korze mózgowej, co prowadzi do większej wydajności recepcyjnej mózgu i lepszej percepcji bodźców zewnętrznych. Doskonalenie sprawności procesów percepcyjnych umożliwia osiągnięcie wyższego poziomu funkcjonowania ucznia w sferze motorycznej, językowej, komunikacyjnej i społeczno-kreatywnej.

Terapia Tomatisa wspomaga działania nauczycieli, rodziców oraz samych dzieci, które uzyskując lepszą sprawność w zakresie percepcji słuchowej i pełniejszą umiejętność wykorzystywania swoich możliwości, mogą skuteczniej doskonalić się w innych obszarach i osiągać pozytywne rezultaty w edukacji szkolnej.

Dobrze jest uświadomić sobie, jak złożonych umiejętności wymaga od dziecka środowisko szkolne i wspierać jego potencjał, myślenie i kreatywność. Warto podkreślić znaczenie wspomagania umiejętności i zdolności słuchowych uczniów poprzez różnorodne formy stymulacji słuchowej.
Radość, jaką dzieci mogą czerpać z pełnego posługiwania się swoim potencjałem słuchowym, jest niezwykle ważna i przekłada się zarówno na budowanie pozytywnego obrazu własnej osoby, jak i lepsze funkcjonowanie społeczno-językowe. Proces uczenia się nie jest tylko zajęciem biernym, jego dopełnieniem jest aktywność własna uczniów na rzecz zdobywania wiedzy.

Poprawa w zakresie uwagi słuchowej może przekładać się na lepszą efektywność w zakresie:

- koordynacji ruchowej, poczucia rytmu, rozbudzenia aktywności ruchowej,

- orientacji w przestrzeni i schemacie ciała (strona prawa i lewa),

- sprawności grafomotorycznej,

- otwartości w zakresie kontaktów społecznych (otwartość komunikacyjna na rówieśników i nie tylko, umiejętność pracy w zespole),

- analizy i syntezy fonemowej,

- pamięci słownej,

- koncentracji uwagi oraz zdolności zapamiętywania,

- odbierania i przekazywania komunikatów werbalnych,

- budowania wypowiedzi dających możliwość odzwierciedlenia własnych myśli,

- pozytywnej postawy w zakresie komunikowania się werbalnego i pozawerbalnego,

- rejestrowania informacji o otaczającym świecie (lepsze rozumienie poleceń kierowanych do dziecka),

- intensywności i różnorodności podejmowanych działań,

- zainteresowania światem i zjawiskami przyrodniczymi,

- kreatywności i dynamizmu życiowego.

\section{Wnioski}

Uzyskane w toku realizacji pierwszej fazy projektu wyniki związane $\mathrm{z}$ wprowadzeniem terapii dźwiękowej jako formy stymulacji słuchowej sugerują korzystny wpływ zastosowania treningu słuchowego oraz wskazują na wartość i zasadność prowadzenia działań wspierających szkolne funkcjonowanie uczniów z wykorzystaniem metody Tomatisa.

Dalsza analiza wyników badań, ich ewaluacja oraz wnioski końcowe będą możliwe po zakończeniu projektu.

\section{Piśmiennictwo:}

1. Bednarska B., Liwo H., Wasila K.: Pierwsze kroki, dźwięki, słowa. Wydawnictwo Galan, Gdańsk, 2009

2. Bellin P., Zilbovicius M., Crozier S.: Lateralization of speech and auditory temporal processing. J Cogn Neurosci, 1998; 10: $536-40$

3. Binder J.R., Frost J.A., Hammeke T.A. i wsp.: Human temporal lobe activation by speech and non - speech sounds. Cerebral Cortex, 2000; 10: 512-28

4. Bonilha A. G., Onofre F., Vieira M.L. i wsp.: Effects of singing classes on pulmonary function and quality of life of COPD patients. Int J Chron Obstruct Pulmon Dis, 2009; 4: 1

5. Bukowska A.: Od emocji po fizjologię, czyli o oddziaływaniu muzyki na organizm człowieka, http://arteterapia.pl/artykuly/ od - emocji - po -fizjologie - czyli o - oddzialywaniu - muzyki-na-organizm-człowieka/ (18.10.2010), 2010
6. Foundas A., Corey D., Hurley M., Heilman K: Verbal dichotic listening lef - handed adults: Laterality effects of directed attention. Cortex, 2006; 42(1): 79-86

7. Gleason J.B. Bernstein Ratner N.: Psycholingwistyka. Gdańsk: Gdańskie Wydawnictwo Psychologiczne, 2005

8. Harwas-Napierała B., Trempała J. (red.) Psychologia rozwoju człowieka. Charakterystyka okresów życia człowieka. Warszawa: Wydawnictwo Naukowe PWN, 2005

9. Kimura D.: Functional assymmetry of the brain in dichotic listening. Cortex, 1967; 3: 163-68

10. Kurkowski Z.M.: Stymulacja audio-psycho-lingwistyczna Metoda Tomatisa. Audiofonologia, 2001; 21: Tom XIX

11. Kurkowski Z.M.: Lateralizacja słuchowa a zaburzenia komunikacji językowej. Audiofonologia, 2002; 21: 179-86

12. Moore D.R., Ferguson M.A., Holliday L.F., Riley A.: Frequency discrimination in children: peception, learning and attention. Hear Res, 2008; 238: 147-54 
13. Pluta A., Skarżyński H.: Mózgowe mechanizmy percepcji emocji generowane przez muzykę. Przegląd literatury: Logopedia, 2009; 38: 203-11

14. Spajdel M., Jariabkova K., Riccansky I.: The influence of musical experience onlateralisation of auditory processing. Laterality, 2007; 12(6): 487-99
15. Święcicka M.: Uwaga. Samokontrola. Emocje. Warszawa: Wydawnictwo Emu, 2005

16. Tomatis A.: L’oreille et le langage. Paryż: Editions du Seuil.,1963

17. Tomatis A.: Loreille et le vie. Paryż: Laffont. Collection Reponse Sante, 1963 